Payments for Ecological Restoration and Internal Migration in China: The Sloping Land Conversion Program in Ningxia

Sylvie Démurger, Haiyuan Wan

December 2012 


\section{GATE Groupe d'Analyse et de Théorie Économique Lyon-St Étienne}

93, chemin des Mouilles 69130 Ecully - France

Tel. +33(0)4 72866060

Fax $+33(0) 472866090$

6, rue Basse des Rives 42023 Saint-Etienne cedex 02 - France

Tel. +33 (0)4 77421960

Fax. +33 (0)4 77421950

Messagerie électronique / Email : gate@gate.cnrs.fr

Téléchargement / Download : http://www.gate.cnrs.fr - Publications / Working Papers 


\title{
Payments for Ecological Restoration and Internal Migration in China: The Sloping Land Conversion Program in Ningxia*
}

\author{
Sylvie Démurger \\ Université de Lyon, Lyon, F-69003, France \\ CNRS, GATE Lyon Saint-Etienne, 93 chemin des Mouilles, Ecully, F-69130, France \\ E-mail: demurger@gate.cnrs.fr

\section{Haiyuan Wan} \\ Institute of Social Development, Academy of Macroeconomic Research, National \\ Development and Reform Commission, Beijing, China \\ $\&$ \\ Université de Lyon, Lyon, F-69003, France; Université Lyon 2, Lyon, F-69007, France; \\ CNRS, GATE Lyon Saint-Etienne, Ecully, F-69130, France \\ E-mail: why842000@163.com
}

\begin{abstract}
This paper analyses the impact of the Sloping Land Conversion Program (SLCP) on rural labor migration in China. We use recent survey data from Ningxia Hui Autonomous Region and a difference-in-difference approach to assess the impact of the policy on labor migration decision. We find a significant effect of the policy: the migration probability increase due to the SLCP policy amounts to 17.5 percentage points in 2008. Furthermore, we highlight the role of policy duration in strengthening the impact of the program on migration. We also find that young, male and Hui nationality individuals are more likely to be impacted by the policy.
\end{abstract}

Key words: Sloping Land Conversion Program; Labor migration; Policy evaluation, China.

JEL Classification: J22; J68; O13; Q23.

\footnotetext{
* Corresponding author: Sylvie Démurger, GATE Lyon Saint-Etienne, 93 chemin des Mouilles, 69130 Ecully, France.
} 


\section{Introduction}

The past decades have witnessed a deterioration of natural environment in China, which led to water shortage, soil erosion, desertification, or ecosystem degradation. After a series of serious drought and flooding in 1997-98, restoring the ecological environment has become a prime task for the Chinese authorities and various reforestation projects have been put on the agenda. As for forest protection itself, the background for the implementation of specific policies can actually be traced back to May 1957 when the State Council passed the "People's Republic of China (PRC) Soil and Water Conservation Program", which stated that the original terraced fields on steep slopes should be gradually returned to forest or pasture. Nevertheless, the most significant changes in the conversion of mountain areas into forest and pasture use as well as in the protection of forest and grassland did not take place before the 1990s, with key legislative steps taken in June 1991 (PRC Law on Water and Soil Conservation), in August 1998 (revised Article 39 of the Law on Land Administration of the PRC) and in January 2000 (Implementation Regulations of the PRC Forestry Law).

A component of the national ecological restoration plan, the Sloping Land Conversion Program $(\mathrm{SLCP})^{1}$ has been set as a priority in the Central Committee's Document No. 2 and the meeting on the Development of China's Western Region in January $2000^{2}$. This large-scale program aimed at reducing soil erosion by returning about 15 million hectare of crop land on steep slopes back to forest or grassland between 2001 and $2010^{3}$, of which 4.4 million hectare of land with a slope over 25 degrees (Xu et al. 2004b). The program also entailed the objective of restructuring the rural economy and reducing poverty through a compensation scheme, which granted participating households the payment of in-kind and cash subsidies for a period of 3 to 8 years ${ }^{4}$. A pilot phase started in 1999 in three provinces (Shaanxi, Sichuan and Gansu). In March 2000, the pilot project was officially

\footnotetext{
${ }^{1}$ The English direct translation of the Chinese official program name (tuigeng huanlin huancao) is "Conversion of Cropland to Forests and Grassland". The program is also known as "Grain-for-Green" Program (Uchida et al. 2009).

${ }^{2}$ The program has been extensively described in the literature. For an up-to-date description, see Yin and Yin (2010).

${ }^{3}$ In August 2007, the General Office of the State Council issued a "Circular on improvement of the Sloping Land Conversion Program", which is regarded as a critical turning point of the program. The new policy adjusted the main planning of the SLCP and the work priorities were shifted from converting large-scale new land to consolidating the existing achievement, hence a shift from quantity extension to forest quality improvement. The program was extended for another 2-8 years with different conservation payments (Chen et al. 2009).

${ }^{4}$ The compensation scheme is described below. It has also evolved over time.
} 
extended, and upon its full-scale implementation by the end of 2002, it involved 25 provinces, autonomous regions and municipalities, and 1,897 counties (Xu et al. 2004a). The total project area covers 710 million hectares, accounting for 74 percent of the total country land area, and the total population in the area is 712 million, of which 78 percent is agricultural population.

The Sloping Land Conversion Program falls into the category of programs implemented worldwide under a scheme of Payments for Environmental Services (PES). As stated by Engel et al. (2008), PES can be defined as "a voluntary transaction where a well-defined environmental service (or a land use likely to secure that service) is being 'bought' by a (minimum one) service buyer from a (minimum one) service provider if and only if the service provider secures service provision" (p. 664). The United States started such programs in 1986 with the implementation of the Conservation Reserve Program (CRP), a long-term reforesting program funded by the government. Similarly, Canada implemented a Permanent Cover Program (PCP) in 1989, and the European Union introduced two land conversion programs as part of the reforms of the Common Agricultural Policy in 1992 (Chen et al. 2009). Various PES programs have also been implemented in developing countries including Costa Rica (Payments for Environmental Services Program), Bolivia (Ecological Compensation System program), Mexico (Payments for Hydrological Environmental Services program), Colombia (Environment Protection Project), or El Salvador (Environment Conservation Program).

Generally speaking, these programs have been found to have a positive impact on environmental protection and on the reduction of soil erosion (Ribaudo et al. 2001; Ferraro and Kiss 2002; Mapemba et al. 2007; Munoz-Pina et al. 2008). In contrast, evidence is mixed regarding their economic impact, especially for household activity choice and labor migration. In the case of the United States and Europe, Cooper and Osborn (1998) and Ferraro and Kiss (2002) found that the implementation of PES programs activated labor migration, but on the contrary, some papers argued that government payments to farmers decreased off-farm labor participation (El-Osta et al. 2004; Dobbs and Pretty 2008), notably because they created an important income effect that outweighed the substitution effect (Ahearn et al. 2006). As for developing countries, the empirical findings on the impact of PES programs on migration are also inconclusive. On one hand, a body of literature shows that reforestation policies have a significant and positive impact on labor migration as well as on household income (Resosudarmo and Thorbecke 1996; Pagiola et al. 2002; Alix-Garcia et al. 2005; Asquith et al. 2008). According to Pagiola et al. (2005), the PES program in Latin America increased 
migration possibilities of rural farmers by about $10 \%$. On the other hand, Wunder (2007) found that the payment price from conversion was too low to change the benefit-cost comparison for rural peasants and their incentives to migrate in Asian developing countries.

The SLCP has also generated considerable interest regarding its effectiveness and its ecological and economic impact ${ }^{5}$ (Yin 2009). So far, most economic papers have analyzed and evaluated the effects of the policy on peasants' income, poverty, and off-farm labor decisions, but very few have been specifically devoted to measuring its impact on labor migration. Table 1 reviews the existing econometric literature and highlights mixed evidence on the labor allocation impact of the program. Papers that used data collected a few years after the program was launched did not find evidence of any impact of the program on off-farm labor participation (Xu et al. 2004a; Uchida et al. 2007), although econometric assessments using more recent data found a positive impact of the SLCP on offfarm labor participation (Uchida et al. 2009; Groom et al. 2010; Yao et al. 2010). A range of descriptive papers argued that most peasants were not willing to participate in the program and that subsidies and free job training would not change their cost-benefit comparison. These papers concluded that the policy had little impact on peasants' participation and labor migration (Xu et al. 2004a; Weyerhaeuser et al. 2005). In the case of Ningxia Hui Autonomous Region, Zhang et al. (2008) also pointed out the limited opportunities for farmers to develop off-farm businesses because of a pervasive lack of investment and policies in local social capital development. They also highlighted the lack of farmers' participation in the policy-making process as a major concern about the sustainability of the program. In contrast, some papers highlighted the attractiveness of the program to households because of the subsidy mechanism, and found that it actually induced a rapid growth of labor migration. For instance, Xu et al. (2006) argued that the SLCP stimulated a small adjustment of the local economies and that participating farmers improved their livelihoods. Liu et al. (2008) reported anecdotal evidence on the large number of surplus laborers generated by the policy that contributed to and facilitated the surge in labor migration across China.

This paper uses a dataset collected in 2009 in Ningxia Hui Autonomous Region to assess whether and to what extent the SLCP has influenced rural labor migration. It aims at answering the following research questions: $i$ ) How labor migration changed in response to government subsidies under the

\footnotetext{
${ }^{5}$ Besides the English-language literature reviewed here, there is also a Chinese-language literature that exhibits similar ambiguity.
} 
SLCP framework? ii) How government policies contributed to the massive rural labor exodus observed in China since the beginning of the 2000s? Despite the number of studies on the socioeconomic impact of the SLCP, there is a lack of knowledge on its impact on labor migration decision at the individual level. Case studies reviewed above are largely based on a few household surveys carried out only a few years after the program implementation in a limited number of provinces (as a matter of fact, most studies focused on the three pilot provinces that started the program first).

Our contribution is three-fold. First, compared to the existing literature, we use a recent dataset that covers the full implementation period of the program and that may enable us to better capture the potentially slow adjustment of household labor allocation decision. Based on these data, our analysis adds to the available literature by examining the SLCP's longer-term impact on labor migration. Second, we specifically focus on labor migration and on individual decisions. The existing literature has mainly assessed the impact of the SLCP on off-farm participation, including local off-farm work and self-employment, and usually only considered labor participation decisions at the family level (to the exception of Uchida et al. 2009). As the drivers of labor migration and other off-farm decision (local self-employment or wage-work) may differ in many respects, focusing on labor migration enables us to provide a somewhat more detailed and consistent analysis by concentrating on the mechanisms through which the policy affects peasants' migration. In terms of the program sustainability, examining labor migration rather than all off-farm activities also makes sense since it not only involves a change of activity out of the farm, but also a displacement of the population out of the countryside. Third, we focus on an autonomous region populated with both Han and minority people that has not been much studied so far, and we use a fairly large and representative sample.

The rest of the paper is organized as follows. Section 1 gives an introduction to the reforestation policy and illustrates how SLCP may affect farmer's decision to migrate. Section 2 provides data description. Section 3 gives an overview of the empirical approach, discusses the identification strategy and reports regression results with the difference-in-difference approach. Section 4 proposes a sensitivity analysis using propensity score matching method. Section 5 concludes. 


\section{The policy design and its expected impact on rural-to-urban migration}

The main purpose of the Sloping Land Conversion Program is to protect ecology and to maintain the natural environment by stopping land cultivation on steep plots that easily lead to soil erosion and on sand land that easily gets desertification. The policy design and implementation have been made as follows ${ }^{6}$. Local governments were responsible for evaluating land and forests. Land plots not suitable for cultivation were set to be returned to forests, and affected farmers have been given compensation, in kind and in cash, per converted hectare. In this design, farmers on erosion-prone sloping land within the upper watershed of the Yangtze River and in the upper and middle parts of the Yellow River have been the main stakeholders involved. The policy includes a grain subsidy (of 1,500 kg per converted hectare per year in the Yellow River basin ${ }^{7}$ ) and a cash subsidy (of 300 Yuan per converted hectare per year) (China National Forestry Economics and Development Research Center 2008). Apart from that, farmers have been granted free seedlings for trees and grass as well as free technical guidance after returning farmland to forests. The government also established some public employment service agencies to provide skill training to farmers, and guidance and help for those choosing to work and live in cities.

A key feature of the program is that the payment for ecological restoration has been designed so as to improve rural household livelihood directly through an increase in income, and indirectly through income source diversification. From a theoretical perspective, the impact of services payments to farmers on labor allocation, and in particular on migration, is unclear. Government payments to farmers typically induce a negative income effect and a positive substitution effect (Ahearn et al. 2006) and a key research question is to assess which effect dominates between the income effect and the substitution effect. On one hand, participating farmers can increase their income if the payments they receive exceed the opportunity cost associated with retiring their land. If the new source of income is large enough to secure their livelihood, the exogenous subsidy may lower the peasants' incentives to diversify their sources of income and thus discourage off-farm work ${ }^{8}$. On the other hand,

\footnotetext{
${ }^{6}$ Zhang et al. (2008) provide a detailed description of the program implementation in Ningxia up to the year 2005. The fundamentals follow the national guidelines.

${ }^{7}$ The grain subsidy has been given to farmers only during the first years of implementation of the program.

${ }^{8}$ Migration and other types of off-farm employment are typical ways to reduce income risk both by diversifying income sources and because these sources of income may be less risky than agricultural income that is highly sensitive to harvest failures and price variations (Taylor and Martin 2001).
} 
by serving as a means to cope with risks and to relax the farmers' liquidity constraints (Key et al. 2006), government payments can be used by farmers to finance other productive, possibly more costly but higher-return activities, both on and off the farm, which may increase their probability to migrate out (Stark and Taylor 1991; Zhao 1999; Uchida et al. 2005). At the same time, the increased leisure time provided to peasants who participate in the program may give them an additional incentive to seek to migrate out (Evenson 1978). As for China, migration is both costly and risky for peasants with low education and skills and with poor access to information, markets and capital, and because of the liquidity constraint, labor migration is usually undertaken by the better-off rural households (Uchida et al. 2009). In this perspective, PES may serve as a redistributive tool and release the financial constraint to allow the poorest to migrate. One may also expect that the longer the peasants participation, the larger the program effect on migration. For all these reasons, the global net effect of SLCP on labor migration is theoretically uncertain and needs to be empirically assessed.

\section{Survey data description}

This paper uses a dataset collected by Hitotsubashi University and Beijing Normal University in 2009 in the Ningxia Hui Autonomous Region. The region lies in the arid and semi-arid areas in the middle reaches of the Yellow River and is sparsely populated. With an area of about 66,400 square kilometers, it is the smallest and among the most ecologically fragile provinces of China. In economic terms, it is also one of the poorest provinces, with a rural per capita annual income of 4,675 yuan in 2010, well below the national average of 5,919 yuan. Another feature that distinguishes the Autonomous Region is that it is populated with both Han and minority people. The Han population accounts for $64.7 \%$ of Ningxia 6.3 million population in 2010 and the largest minority group, the Hui nationality, accounts for $34.6 \%$ of Ningxia total population (Statistical Bureau of Ningxia Hui Autonomous Region 2011).

The investigation was implemented from March to April 2009, and was especially designed for research on the Sloping Land Conversion Program (SLCP). A stratified random sampling method was used to collect the data, and the survey investigated 3 prefecture-level cities, 9 counties, 60 villages and 800 peasants. Figure 1 shows the location of the surveyed prefecture-level cities and counties. Ningxia Hui Autonomous Region is made up of 5 prefecture-level cities and 11 counties. The 2 non- 
surveyed prefectures are located in the Northern richer part of the autonomous region and include the capital city, Yinchuan. The 3 prefecture-level cities surveyed are the poorest, with an average rural household net income per capita ranging from 3,477 to 5,041 yuan in 2010 (Statistical Bureau of Ningxia Hui Autonomous Region 2011). On average, one village was randomly selected in each township, and thirteen randomly sampled households were interviewed in each village. Collected information includes family and individuals' basic information, labor migration, employment, income and expenditure, consumption and information on SLCP participation. Enumerators were requested to ask the household to recall the related information for the years 2002 and 2008. In the following analysis, information for the year 2008 will be treated as after-policy information, while information for the year 2002 will be treated as pre-policy information. Two sources of potential bias must be acknowledged here. First, as highlighted in Uchida et al. (2009), recall data may be subject to a recall bias. However, as we focus on migration participation and not on migration duration or on wage income, we may expect households to remember more clearly whether or not household members were migrating in 2002. Second, and potentially more important, there could be a selection bias if a large number of rural households had (permanently) migrated elsewhere between 2002 and 2008. Unfortunately, the survey does not document this issue, which does not enable us to assess to what extent migrated households could affect our results. Nevertheless, given that permanent migration remains very limited in China due to strong institutional constraints (notably through the Hukou household registration system), we expect the bias not to be too strong though we acknowledge the potential for problems related to this issue.

The survey collected 800 valid household questionnaires, with 500 SLCP participating households (62.5\% of the sample) and 300 non-participating households. At the village level, $53.3 \%$ of the surveyed villages had a $100 \%$ participation share while $21.7 \%$ (13 villages) had no conversion at all in 2008. On average, the household participation share at the village level in 2008 was $66.67 \%$.

Regarding SLCP participation, the participating peasants did not all enter the program at the same time. The program was first implemented in 2000, with only 6 households enrolled in our sample. In the following years, the program progressively expanded, with $23,52,128,187$, and 104 additional households entering the program in 2001, 2002, 2003, 2004 and 2005 respectively. In order to use the difference-in-difference method (see below), we should only keep peasants who did not enter the program before 2002, considered as our pre-policy year. As a consequence, we have dropped from the 
sample the 29 households who entered the program before 2002, and we are left with 471 households in the participating group 9 . The participation duration in the program for participating peasants ranges from 3 to 6 years at the end of 2008, with an average of 4.27 years. Finally, we restrict our sample of individuals to the working-age population (aged between 16 and 65) so that we have 1,000 individuals (300 households) in the non-participating group and 1,673 individuals (471 households) in the participating group.

The exogeneity of the SLCP policy has been established by the existing literature (Uchida et al. 2009). Though in principle the peasants' involvement was based on "voluntary" participation, anecdotal evidence indicates that in practice, local governments often focused on the natural condition of the land as the main criterion for determining the land and the area to convert. Tao et al. (2004) argue that most peasants did not have the option to choose whether they can participate in the program or not, how much land they had to return, and what kind of trees they could plant on the returned farmland. As demonstrated in Zuo (2001) and Bennett and Xu (2008), the targeting of areas to retire has generally been conducted via a top-down approach, starting with retirement quotas that were distributed from the central government to the provinces, followed by subsequent distribution down through counties, townships and finally to participating villages. Then the local government would decide on peasants' participation in the program on a land criterion, with impoverished lands on steep hills and far away from the village being designed to return to forest. Xu et al. (2010) also point to the fact that households have had unequal access to the program, and in some cases, have been forced to participate when they would otherwise have not. In our own sample, the compulsory nature of the policy appears from a set of questions. In the participating group, about three quarters of the participating households reported having no or limited choice to participate when entering the program. Moreover, to the question(s) "Were you free to choose the area (the land) to return to forest?", 95 percent answered "No, it has been compulsorily arranged by the village or government". On the other hand, 72 percent in the non-participating group declared being willing to participate. As peasants' will was clearly not taken into consideration, the policy can be treated as being largely exogenous to rural households ${ }^{10}$.

\footnotetext{
${ }^{9}$ We chose to keep the households who converted land in 2002 as we may confidently expect at least a few months lag between entering the program and adapting migration behavior. Nevertheless, excluding households who entered the program in 2002 does not change our key results.

${ }^{10}$ Still, one may argue that one quarter of the participating respondents did not answer having no or limited
} 
Land characteristics further confirm that plots with poor geographical characteristics, far away from home, with a steep slope and of a poor quality were more likely to be returned to forest than kept as cultivated land. Available data for SLCP participating households in the survey highlight large differences between converted and non-converted plots in slope, distance to home and land quality, all criteria chosen by the government to decide on land conversion (Table 2). As for land slope, only 14 percent of the converted land is flat, while the share amounts to 52 percent for non-converted plots, which indicates that higher quality and flat land is still cultivated. In contrast, more than 59 percent of the converted land has a slope higher than 25 percent, against 23 percent for non-converted plots. Regarding land quality, more than 45 percent of the converted land was reported by households as of a bad or very bad quality, while the corresponding figure for non-converted land is less than 4 percent.

Table 3 displays summary statistics on individual and household characteristics by participation status. Generally speaking, individuals in the participating group are more educated: the proportion of individuals in the non-participating group who have received only primary (or no) education amounts to $55.5 \%$ while that of individuals in the participating group is $49.5 \%$. Moreover, there is a clear distinction between Han and Hui people, with the former being significantly more largely represented in the participating group. Besides education and ethnicity, no other individual characteristics appear to be significantly different between the participating and the non-participating groups.

As for our outcome variable of interest, Table 3 shows very different migration patterns between the participating and the non-participating groups. In this analysis, we identify migrants as household members who declared working outside their home township for at least one month during the year of interest ${ }^{11}$. As shown in Table 3, the propensity to migrate in 2008 is significantly higher in the participating group (28.3 percent) compared to the non-participating group (17.6 percent). Interestingly, the initial village shares of migrants highlight a reverse picture: for the non-participating group, the proportion of migrants in the village labor force was 25.8 percent in 2002, compared to 21.7 percent for the participating group. Given the design of the policy, these statistics are consistent with

\footnotetext{
choice to participate and that this may affect our results. In the empirical analysis, we use a matching approach as a sensitivity analysis, which allows us to partly account for this issue. The matching method aims at constructing a statistical comparison group based on a model of the probability of participating, using observed characteristics. Even if the policy is not fully exogenous to households, we believe that the assumption of conditional independence holds since SLCP participation criteria have been largely based on observable land characteristics.

${ }^{11}$ Imposing a three-month duration does not change the results, except that it reduces the share of migrants by 2.5 percentage points on average (see Table 3 ).
} 
the targeting of remote hilly lands: in remote villages, the incidence of labor migration is usually lower because of higher associated migration costs. This is confirmed by the significantly longer distance to the county seat for the participating group $(45.6 \mathrm{~km}$ on average against $33.6 \mathrm{~km}$ for the nonparticipating group).

With regard to household characteristics at baseline (2002), individuals in the participating group belong to households with more adults and fewer elderly, and a smaller land endowment per adult at the beginning of the program. The average land endowment per person is $8.22 m u^{12}$ per person, as compared to 11.55 for non-participating households.

\section{The impact of the Sloping Land Conversion Program on labor migration}

\section{1. Empirical approach}

Our objective is to assess whether the Sloping Land Conversion Program has been effective in increasing rural labor migration among participating peasants. To do so, we construct a "natural experiment" from the policy and we test whether rural labor migration patterns are significantly different between SLCP participating individuals and non-participating individuals. We use a difference-in-difference (DD) approach to measure the net effect of the SLCP policy on labor migration, with a simple case of a two-group two-period model for the outcome.

Let us consider that the SLCP participating peasants are the treatment group $(\mathrm{T}=1)$ and the nonparticipating peasants are the control group $(\mathrm{T}=0)$. The time before the policy implementation is denoted $t_{0}$, and the time after $t_{1}$. The difference-in-difference estimator is given by:

$$
D D=E\left(Y_{t_{1}}-Y_{t_{0}} \mid T=1\right)-E\left(Y_{t_{1}}-Y_{t_{0}} \mid T=0\right)
$$

where $Y_{t}$ is the outcome of interest (migration in our case) for an individual $i$ (either treated or not treated) at time $t$. The first difference (within parentheses) eliminates individual systematic effects and the second difference (between parentheses) eliminates time effects that are common to both groups.

In practice, it can be translated into the following estimation model:

$$
Y_{i t}=\beta_{0}+\beta_{1} \times \text { Year }_{t}+\beta_{2} \times \text { Treated }_{i}+\beta_{3} \times\left(\text { Year }_{t} * \text { Treated }_{i}\right)+\varepsilon_{i t}
$$

where $t$ indexes the year, and $i$ indexes the individual. The variable Year is a dummy variable that

\footnotetext{
${ }^{12}$ One $m u$ is equal to 0.067 hectare.
} 
equals 1 after the policy implementation (and 0 otherwise). The variable Treated is a dummy variable that indicates whether the individual belongs to a SLCP participating household (and 0 otherwise). The coefficient $\beta_{3}$ of the interaction term Year*Treated is the coefficient of interest that measures the net impact of the policy on labor migration.

The main identification condition for the estimation of the SLCP effect is that there are no other shocks than the new policy that may affect the differential migration decision of the participating group relative to the non-participating group. We control for as many observables (at the individual, the household and the village levels) as possible to fill up this kind of deficiency, and we estimate the following linear probability equation for the likelihood of migration in year $t$ :

$$
Y_{i t}=\beta_{0}+\beta_{1} \times \text { Year }_{t}+\beta_{2} \times \text { Treated }_{i}+\beta_{3} \times\left(\text { Year }_{t}^{*} \text { Treated }_{i}\right)+\gamma X_{i t}+\varepsilon_{i t}
$$

The vector $X$ contains time invariant or time-varying control variables, such as gender, age, education, marital status, ethnicity, family composition, land area per person, village migration networks and distance to the county seat; $\varepsilon$ is the error term for the unobservable factors that affect labor migration. The estimations rely on linear models (OLS) for the binary dependent variable that have the advantage over logit or probit models to provide a straightforward causal interpretation (Angrist and Pischke 2008). Moreover, individual decisions are assumed not to be independent across members of a given household and estimations are run allowing for intra-household correlations through a cluster effect.

\section{2. Estimation results from DD model}

To start with, Table 4 reports simple descriptive statistics for migration propensity by treatment and by year. Reading rows first emphasizes the differences between the two groups of farmers. Before the implementation of the SLCP policy, the subsequent non-participating group was more involved in migration than the subsequent participating group, with a 6.8 percentage points difference. The outcome is totally reversed after the policy, since the participating group exhibits a higher migration share than the non-participating group. The difference-in-difference (DD) estimate of $17.5 \%$ is the difference between a negative pre-intervention difference and a positive post-intervention difference, leading to a strongly positive DD estimate.

Before presenting the estimation results for equation (3), Table 5 displays individual migration 
status changes between 2002 and 2008 that may help understanding the transition patterns. The internal migration phenomenon in China is characterized by its temporary nature, with somehow important return migration (Démurger and Xu 2011). Interestingly, Table 5 shows that in our sample, return migration is much more important for the non-participating group than for the participating group between 2002 and 2008. Hence, the reversed migration shares observed in Table 4 are derived from a combination of higher return migration rates and lower new migration rates for the nonparticipating group.

Table 6 reports various estimation results of equation (3). The coefficient of interest appears in the third row: it measures the impact of the Sloping Land Conversion Program on labor migration for participating individuals relative to non-participating individuals. As the coefficient for the interaction term is positive and significant, estimations confirm that the policy has been effective in contributing to rural labor force exodus. The estimates suggest that program participation increased the migration probability by 17.5 percentage points in 2008 compared to the observed changes in the non-treated group.

Table 6 also demonstrates that migration decision depends on a set of various factors related to socioeconomic and family characteristics. Migrants are young ${ }^{13}$ male individuals with an education level of about 6 to 9 years $^{14}$, all characteristics consistent with standard findings in the empirical literature on China (see Zhao (2005) for a review). In contrast, after controlling for age, gender and family characteristics, we do not find any significant difference in migration probability between Han and Hui nationality groups or between married and non-married individuals.

In terms of family characteristics, household composition and assets at baseline all have a significant effect on labor migration. First, we find that the number of adults in the family significantly increases the individual probability to migrate whereas the number of dependents, both young and old, significantly reduces the probability to migrate. A larger labor force reduces the opportunity cost for the family to send migrants to cities but a higher dependency ratio of the household significantly reduces family labour availability for migration. Second, the household per capita land holding in

\footnotetext{
${ }^{13}$ The significant estimates for age and age squared indicate that migration participation increases with age up to a threshold level of about 29 years old (in 2002).

${ }^{14}$ The reference group for education level is "above 9-year compulsory education". Regarding education, its role in rural migration in China has been found ambiguous in the literature (Zhao 2005). In particular, there is evidence that better educated individuals tend to choose local off-farm work over migration, which could also explain that more educated persons are less likely to migrate than junior-school-educated persons in our sample.
} 
2002 is unsurprisingly found to have a negative and significant impact on labor migration. It reflects the demand for farm labor, and in the specific case of China, it may also reflect the need for households to keep farming their land if they want to protect their land use rights. Once the labor force size is controlled, only families with smaller landholdings can afford sending household members to migrate. Finally, at the village level, we find that existing migration networks in 2002 play a significant and positive role in peasants' migration decision. A higher proportion of migrants in the village labor force can indeed help reducing information collection costs and psychological costs associated with migration.

To further explore the labor migration impact of SLCP participation, we consider three variants that reflect differences in the intensity of program participation: the duration in the policy (measured by the number of years in the program), the program area (measured by the converted area) and the participation intensity (measured by the ratio of converted area to total landholdings). Estimation results are reported in Table 6, columns (2) to (4). All the coefficients for the interaction terms are positive and significant, which indicates that a deeper participation favored labor migration. The strongest impact is found for the intensity of participation in the program: our estimates suggest an increase in the migration probability by 20.7 percentage points for a one percent increase in the ratio of program area to total land area. Both duration in the program and the area converted are also found to facilitate migration, with coefficient estimates of 0.0344 and 0.00192 respectively. These results confirm the program effectiveness in facilitating labor migration for participating farmers. Interestingly, the estimated magnitude of the effects for both participation intensity and duration is very close to Uchida et al. (2009) findings. We find slightly higher effects though (0.207 against 0.159 for intensity and 0.0344 against 0.020 for duration), which is consistent with the view of a potentially slow adjustment of household labor allocation decision ${ }^{15}$ after the policy is implemented. As our study covers a longer project implementation period than most previous studies, we are able to highlight the role of policy duration in strengthening the impact of the SLCP on migration. This finding confirms the importance of sustaining the policy over time since labor allocation adjustments may not be immediate but instead require a few years before being visible.

\footnotetext{
${ }^{15}$ Two differences between Uchida et al. (2009) analysis and our analysis are worth emphasizing here. First, their analysis is based on (post-program) data for the year 2004, which is rather early in the period of implementation. Second, they do not specifically focus on labor migration, and more generally look at off-farm work, which also includes local wage work and self-employment.
} 


\section{3. Program heterogeneous effects by sub-groups}

Once we have established the effectiveness of the SLCP in encouraging labor migration, an additional question arises as to which farmers are more likely to shift to migration after the implementation of the policy. In order to assess the potential heterogeneity of the impact of the program on various groups of individuals, we consider separately five dimensions (gender, age, education, marital status and ethnicity) and re-run regressions by introducing interaction terms with the 'treatment $\mathrm{x}$ year' variable for each dimension. As can be seen from Tables 7 and 8 , we find notable differences when we stratify by age, gender and ethnicity, but no significant difference by education or marital status.

Participating in the program increases the propensity to migrate of the youngest age cohort (between 15 and 29 years) by 12.9 percentage points. The effect then becomes insignificant for the 30 39 and 40-49 age cohorts, and negative (and significant) for the 50-66 age cohort. The age pattern heterogeneity clearly follows the age profile of rural migrants in China: following the standard human capital theory, an explanation for the higher migration propensity is that young people can receive a longer return stream from their human capital investment activity. The key interesting finding here is that this age-migration pattern is being reinforced by the program, which further increases the migration propensity of the youngest.

Regarding gender differences, we find a positive responsiveness of migration to the SLCP policy significantly stronger for men than for women: male propensity to migrate increases by 13.5 percentage points thanks to the policy. Again, the gender difference that is usually observed in migration patterns is being reinforced by the policy. In this specific context, there may be many reasons to account for such a result, among them the fact that male peasants are less involved in taking care of their young children or of the elderly, both dependent groups found to negatively affect individual propensities to migrate.

An interesting result is found when stratifying the sample by ethnicity. As shown above, Hui nationality people are not likely to migrate more than Han individuals. However, Table 8 shows that the impact of the SLCP is significantly stronger for Hui people than for Han people. Such heterogeneity in the SLCP impact by ethnicity suggests that different assignment rules of the program could have increased the overall impact of the program on migration. Indeed, the household participation rate was actually much smaller for the group of Hui nationality households: $56 \%$ of this 
group participated in the program as compared to $67 \%$ for Han households. Hence, the program seemingly favored Han households and did not fully reach ethnic minorities. Given the stronger impact of the program on Hui individual migration propensity, targeting minority groups in the program selection could have produced higher rates of migration.

\section{Propensity score matching analysis}

In the analysis conducted in section 3, we have implicitly assumed that the Sloping Land Conversion Program had clear assignment rules that explained why some households enrolled in the program while others did not. However, if the assignment of households to the treatment and control groups is not random, then the estimation of the average treatment effect may be biased because of confounding factors. As a sensitivity analysis, we now relax the assumption of clear assignment rules and use matching method to identify a comparison group that matches the treatment group, based on the most similar observed characteristics. The matching is achieved on the probability to participate in the Sloping Land Conversion Program.

We follow the Propensity Score Matching (PSM) approach proposed by Rosenbaum and Rubin (1983). We first use a logit model to estimate the propensity score for each observation in the participant and the non-participant groups; we then match individuals in the non-participating group to individuals in the participating group who have similar propensity scores; and we compare the outcome indicator between the two groups ${ }^{16}$. A key feature of the propensity score matching method is to create a randomized experiment to match the two groups. Since the characteristics of the two groups are similar, the migration difference can thus be attributed to the contribution of the program.

Before presenting the average treatment effects obtained through PSM, we have performed preliminary tests for common support and covariate balancing. As stated by Becker and Ichino (2002), imposing the common support condition in the estimation of the propensity score may improve the quality of the matches used to estimate the average treatment effects. We impose the common support condition, which means that we consider only the observations whose propensity score belongs to the intersection of the supports of the propensity score of the treated and the controls. In our case, the propensity score that lies within the interval $[0.37,0.80]$ overlaps for both the treated and the control

\footnotetext{
${ }^{16}$ The empirical implementation is made using the Stata programs developed by Leuven and Sianesi (2003).
} 
groups (see Figure 2 for Kernel matching method). We also test the balancing characteristics for all the covariates, the basic idea of this step being to compare the situation before and after matching and to make sure there are no differences after conditioning on the propensity score.

Several matching methods have been proposed in the literature, the most widely used being the Nearest-Neighbor matching, the Radius matching, and the Kernel matching methods. Table 9 presents the average treatment effect on the treated (ATT) obtained from different matching methods and different sets of parameters, together with bootstrapped standard errors. Results in this table show that the ATT is very stable across the alternative methods of matching and is significant. The measured ATT ranges from $15.76 \%$ to $16.20 \%$, which confirms the effectiveness of the Sloping Land Conversion Program in promoting labor migration.

\section{Conclusion}

The Sloping Land Conversion Program (SLCP) implemented in China from 2000 aimed at reducing soil erosion and protecting the environment by converting crop land on steep slopes back to forest or grassland. As a Payments for Environmental Services program, it included a monetary compensation for participating farmers, which was expected to contribute alleviating rural poverty and to favor rural restructuring.

This paper assesses the effectiveness of the policy in increasing individual labor migration probability in the case of Ningxia Hui Autonomous Region, by using a difference-in-difference (DD) approach and propensity score matching. The main findings can be summarized as follows. First, we find evidence of a positive net impact of the SLCP on rural labor migration in three poor prefecturelevel cities in Ningxia Hui Autonomous Region. One may conclude from these findings that government payments have been effective in facilitating the labor exodus of the 2000s in a poor region of China not well-connected to the developed eastern part. This is particularly confirmed by the fact that participating villages were not the most migrant-sending villages prior to the policy. As a consequence, the policy seems to have been an effective tool in encouraging migration for the most remote, poorest villages. One may infer from these results that in the case of Ningxia, government payments for ecological restoration have induced a positive substitution effect for farmers that outweighed the negative income effect of the policy. In this perspective, the policy enabled poor 
individuals to shift to costly but higher-return activities. Second, as our study covers a longer project implementation period than most previous studies, we are able to better highlight the role of policy duration in strengthening the impact of the SLCP on migration. This is also an interesting finding since it emphasizes the importance of the time dimension in assessing the impact of the policy: a compensation policy can be an effective tool in favoring labor reallocation in rural remote places towards migration, but it must be sustained over time to ensure a longer-term impact on migration because reallocation may not be straightforward. Third, we find a larger impact of the program for young, male and Hui people. Our finding of a stronger impact of the policy on Hui nationality people points to an additional (and potentially unintended) outcome of the policy in facilitating migration for ethnic groups which are not the most likely to migrate otherwise. As minority groups of individuals are usually poorer, more remote and lack access to formal credit or insurance markets, these results may also be interpreted as indirectly pointing to the importance of financial constraints in migration decision.

Although our results suggest that the Sloping Land Conversion Program has been effective in encouraging rural activity diversification, its effective contribution to rural poverty alleviation is not straightforward and depends on many economic and institutional factors. Among other channels, the SLCP impact on poverty alleviation depends on how the labor reallocation within households has been accompanied by transfers from migrants to the left-behinds. In the absence of adequate income and transfer data, we could not test for this. Moreover, the long-term sustainability of policies encouraging migration is not guaranteed given the huge institutional barriers that still limit the access of rural migrants to urban residency.

\section{Acknowledgment}

We thank Li Shi (Beijing Normal University) and Hiroshi Sato (Hitotsubashi University) for giving us access to the data. The data collection has been financially supported by JSPS Grant for Scientific Research No.18203018 and No.21330065, Heiwa Nakajima Foundation, Research Unit for Statistical and Empirical Analysis in Social Sciences (G-COE Hi-Stat), and Hitotsubashi University. We are grateful to an anonymous referee for useful suggestions. We are also thankful to participants at the International Workshop on Migration and Development in Lille November 2011 and the EALE Annual Conference in Bonn September 2012. 


\section{References}

Ahearn Mc, El-Osta H, Dewbre J (2006) The Impact of Coupled And Decoupled Government Subsidies on Off-Farm Labor Participation of U.S. Farm Operators. American Journal of Agricultural Economics 88(2):393-408.

Alix-Garcia J, De Janvry A, Sadoulet E (2005) A Tale of Two Communities: Explaining Deforestation in Mexico. World Development, 33:219-235.

Angrist JD, Pischke JS (2008) Mostly Harmless Econometrics: An Empiricists Companion. Princeton University Press, Princeton.

Asquith NM, Vargas MT, Wunder S (2008) Selling Two Environmental Services: In-Kind Payments for Bird Habitat and Watershed Protection in Los Negros, Bolivia. Ecological Economics 65(4):675-684.

Becker SO, Ichino A (2002) Estimation of Average Treatment Effects Based on Propensity Scores. STATA Journal 2(4):358-377.

Bennett MT, Xu J (2008) China's Sloping Land Conversion Program: Institutional Innovation or Business as Usual? Ecological Economics 65(4):699-711.

Chen X, Lupi F, He G, Ouyang Z, Liu J (2009) Factors Affecting Land Reconversion Plans Following a Payment for Ecosystem Service Program. Biological Conservation 142(8):1740-1747.

China National Forestry Economics and Development Research Center (2008) A Report for Monitoring and Assessment of the Socio-Economic Impacts of China's Key Forestry Programs 2006. China Forestry Publishing House.

Cooper JC, Osborn T (1998) The Effect of Rental Rates on The Extension of Conservation Reserve Program Contracts. American Journal of Agricultural Economics 80:184-194.

Démurger S, Xu H (2011) Return Migrants: The Rise of New Entrepreneurs in Rural China. World Development 39(10):1847-1861.

Dobbs TL, Pretty J (2008) Case Study of Agri-Environmental Payments: The United Kingdom. Ecological Economics 65(4):765-775.

El-Osta H, Mishra A, Ahearn M (2004) Labor Supply by Farm Operators under "Decoupled" Farm Program Payments. Review of Economics of the Household 2(4):367-385.

Engel S, Pagiola S, Wunder S (2008) Designing payments for environmental services in theory and practice: An overview of the issues. Ecological Economics 65(4):663-674.

Evenson R (1978) Time Allocation in Rural Philippine Households. American Journal of Agricultural Economics 60:302-322.

Ferraro PJ, Kiss A (2002) Direct Payments to Conserve Biodiversity. Science 298:1718-1719.

Groom B, Grosjean P, Kontoleon A, Swanson T, Zhang S (2010) Relaxing Rural Constraints: A 'WinWin' Policy for Poverty and Environment In China? Oxford Economic Papers 62(1):132-156.

Key N, Roberts M, O’Donoghue E (2006) Risk and Farm Operator Labour Supply. Applied Economics 38(5):573-586.

Leuven E, Sianesi B (2003) PSMATCH2: Stata Module to Perform Full Mahalanobis and Propensity Score Matching, Common Support Graphing, and Covariate Imbalance Testing. http://ideas.repec.org/c/boc/bocode/s432001.html.

Liu JG, Li SX, Ouyang ZY, Tam C, Chen X (2008) Ecological and Socioeconomic Effects of China's Policies for Ecosystem Service. Proceedings of the National Academy of Sciences of the United 
States of America, 105:9477-9482.

Mapemba L, Epplin F, Taliaferro C, Huhnke R (2007) Biorefinery Feedstock Production on Conservation Reserve Program Land. Review of Agricultural Economics, 29:227-246.

Munoz-Pina C, Guevara A, Torres JM, Braña J (2008) Paying for the Hydrological Services of Mexico's Forests: Analysis, Negotiations and Results. Ecological Economics 65:725-736.

Pagiola S, Arcenas A, Platais G (2005) Can Payments for Environmental Services Help Reduce Poverty? An Exploration of the Issues and Evidence to Date From Latin America. World Development 33(2):237-253.

Pagiola S, Landell-Mills N, Bishop J (2002) Market-Based Mechanisms for Forest Conservation and Development. London, UK, Earthscan Publications Ltd.

Resosudarmo BP, Thorbecke E (1996) The Impact of Environmental Policies on Household Incomes for Different Socio-Economic Classes: The Case of Air Pollutants in Indonesia. Ecological Economics 17(2):83-94.

Ribaudo MO, Hoag DL, Smith ME, Heimlich R (2001) Environmental Indices and the Politics of the Conservation Reserve Program. Ecological Indicators 1:11-20.

Rosenbaum P., Rubin D (1983) The Central Role of the Propensity Score in Observational Studies for Causal Effects. Biometrika 70:41-55.

Stark O, Taylor JE (1991) Migration Incentives, Migration Types: The Role of Relative Deprivation. Economic Journal 101:1163-1178.

Statistical Bureau of Ningxia Hui Autonomous Region (2011), Ningxia Statistical Yearbook 2011, China Statistics Press.

Tao R, Xu Z, Xu J (2004) Grain for Green Project, Grain Policy and Sustainable Development. Social Sciences in China 6(11):25-38.

Taylor J E, Martin P L (2001) Human capital: Migration and rural population change. In: Rausser GC, Gardner B (Ed) Handbook of Agricultural Economics. North-Holland, Amsterdam.

Uchida E, Rozelle S, Xu J (2009) Conservation Payments, Liquidity Constraints and Off-Farm Labor: Impact of the Grain for Green Program on Rural Households in China. American Journal of Agricultural Economics 91(1):70-86.

Uchida E, Xu J, Rozelle S (2005) Grain for Green: Cost-Effectiveness and Sustainability of China's Conservation Set-Aside Program. Land Economics 81:247-264.

Uchida E, Xu J, Xu Z, Rozelle S (2007) Are the Poor Benefiting from China's Conservation Set-Aside Program? Environment and Development Economics 12:593-620.

Weyerhaeuser H, Wilkes A, Kahrl F (2005) Local Impacts and Responses to Regional Forest Conservation and Rehabilitation Programs in China's Northwest Yunnan Province. Agricultural Systems 85:234-253.

Wunder S (2007) The Efficiency of Payments for Environmental Services in Tropical Conservation. Conservation Biology 21:48-58.

Xu J, Bennett MT, Tao R, Xu J (2004a) China's Sloping Land Conversion Program Four Years on Current Situation, Pending Issues. International Forestry Review 6(3-4):317-326.

Xu J, Tao R, Xu Z (2004b) Sloping Land Conversion Program: Cost-Effectiveness, Structural Effect and Economic Sustainability. China Economic Quarterly 4(1):139-161.

Xu J, Tao R, Xu Z, Bennett MT (2010) China's Sloping Land Conversion Program: Does Expansion Equal Success? Land Economics 86(2):219-244.

Xu J, Yin R, Li Z, Liu C (2006) China's Ecological Rehabilitation: Unprecedented Efforts, Dramatic 
Impacts, and Requisite Policies. Ecological Economics 57:595-607.

Yao S, Guo Y, Huo X (2010) An Empirical Analysis of the Effects of China's Land Conversion Program on Farmers' Income Growth and Labor Transfer. Environmental Management 45(3):502-512.

Yin R (2009) An Integrated Assessment of China's Ecological Restoration Programs. Springer Netherlands.

Yin R, Yin G (2010) China's Primary Programs of Terrestrial Ecosystem Restoration: Initiation, Implementation, and Challenges. Environmental Management 45(3):429-441.

Zhang L, Tu Q, Mol A (2008) Payment for environmental services: The Sloping Land Conversion Program in Ningxia Autonomous Region of China. China \& World Economy 16(2):66-81.

Zhao Y (1999) Leaving the Countryside: Rural-To-Urban Migration Decisions in China. American Economic Review 89(2):281-286.

Zhao Z (2005) Migration, Labor Market Flexibility, and Wage Determination in China: A Review. The Developing Economies 43(2):285-312.

Zuo T (2001) Implementation of the Sloping Land Conversion Program. In: Xu J, Katsigris E, White Ta (Ed) Implementing the Natural Forest Protection Program and the Sloping Land Conversion Program: Lessons and Policy Implications. China Forestry Publishing House, Beijing. 
Table 1 - Key literature findings on the impact of the SLCP on labor migration

\begin{tabular}{|c|c|c|c|c|c|}
\hline Reference & $\begin{array}{l}\text { Studied } \\
\text { zone }\end{array}$ & $\begin{array}{c}\text { Year of } \\
\text { investigation }\end{array}$ & Data & Method & $\begin{array}{c}\text { Key findings on labor } \\
\text { migration }\end{array}$ \\
\hline $\begin{array}{l}\text { Uchida et al. } \\
(2007)\end{array}$ & $\begin{array}{c}\text { Sichuan, } \\
\text { Shaanxi, } \\
\text { Gansu }\end{array}$ & 2003 & $\begin{array}{c}\text { 1999, 2002; } 359 \\
\text { households }\end{array}$ & $\begin{array}{c}\text { Household level } \\
\text { PSM / DD }\end{array}$ & $\begin{array}{l}\text { No significant program } \\
\text { impact on change in labor } \\
\text { allocation into off-farm } \\
\text { work or migration. }\end{array}$ \\
\hline $\begin{array}{l}\text { Uchida et al. } \\
(2009)\end{array}$ & $\begin{array}{l}\text { Sichuan, } \\
\text { Shaanxi, } \\
\text { Gansu }\end{array}$ & $2003 \& 2005$ & $\begin{array}{l}\text { 1999, 2002, 2004; } \\
\text { 270 households }\end{array}$ & $\begin{array}{l}\text { Individual level } \\
\text { DD / matching }\end{array}$ & $\begin{array}{l}\text { Participating households } \\
\text { more likely to shift to off- } \\
\text { farm labor, thanks to } \\
\text { liquidity constraint } \\
\text { relaxation. Stronger } \\
\text { impact for young and } \\
\text { educated individuals. }\end{array}$ \\
\hline $\begin{array}{l}\text { Groom et al. } \\
(2010)\end{array}$ & $\begin{array}{l}\text { Ningxia, } \\
\text { Guizhou }\end{array}$ & 2004 & $\begin{array}{l}\text { 1999, 2003; } 286 \\
\text { households }\end{array}$ & $\begin{array}{l}\text { Household level } \\
\text { Switching } \\
\text { regression \& DD }\end{array}$ & $\begin{array}{l}\text { Heterogeneous impact } \\
\text { across households / A } \\
\text { positive program impact } \\
\text { on labor reallocation } \\
\text { towards local off-farm } \\
\text { work, but a negative } \\
\text { impact on migration }\end{array}$ \\
\hline $\begin{array}{l}\text { Yao et al. } \\
(2010)\end{array}$ & $\begin{array}{c}\text { Shaanxi, } \\
\text { Gansu }\end{array}$ & 2007 & $\begin{array}{c}1999,2006 \\
600 \text { households }\end{array}$ & $\begin{array}{l}\text { Household level } \\
\text { DD }\end{array}$ & $\begin{array}{l}\text { Significant positive } \\
\text { impact of program } \\
\text { participation on the } \\
\text { transfer of farming labor } \\
\text { to off-farm activities. }\end{array}$ \\
\hline
\end{tabular}


Table 2 - Land characteristics for participating households

\begin{tabular}{lcc}
\hline & Converted land & Non-converted land \\
\hline Slope of the land (\%) & & \\
Flat & 14.21 & 51.99 \\
Gentle slope & 26.26 & 24.94 \\
Steep slope (more than 25 percent) & 59.53 & 23.06 \\
Minutes walk to plots & 30.45 & 20.67 \\
Land quality compared to other land within the village (\%) & & \\
Very good & 2.50 & 17.88 \\
Good & 15.49 & 46.19 \\
So-so & 36.70 & 32.17 \\
Bad & 29.15 & 3.20 \\
Very bad & 16.16 & 0.55 \\
\hline Sample size (plots) & 1,801 & 1,812 \\
\hline
\end{tabular}

Source: Survey data collected by Beijing Normal University and Hitotsubashi University in 2009.

Notes: Land characteristics are only available for participating households. The survey asked participating households to report land characteristics for up to five plots for each category of land, converted or nonconverted. Numbers reported in the table are averages over all declared in each category. 
Table 3 - Summary statistics for participating and non-participating individuals, 2008

\begin{tabular}{|c|c|c|c|c|}
\hline & Total & $\begin{array}{c}\text { Participating } \\
\text { group }\end{array}$ & $\begin{array}{c}\text { Non-participating } \\
\text { group }\end{array}$ & Mean test \\
\hline \multicolumn{5}{|l|}{ Individual characteristics } \\
\hline Gender ( $\%$ male $)$ & 0.519 & 0.523 & 0.511 & NS \\
\hline Age (years) & 35.68 & 35.69 & 35.66 & NS \\
\hline Hui nationality & 0.413 & 0.375 & 0.477 & $* * *$ \\
\hline Marital status (married \%) & 0.681 & 0.674 & 0.693 & NS \\
\hline Education (primary \& below) & 0.517 & 0.495 & 0.555 & $* * *$ \\
\hline $\begin{array}{l}\text { Education (junior middle } \\
\text { school) }\end{array}$ & 0.310 & 0.330 & 0.277 & $* * *$ \\
\hline $\begin{array}{l}\text { Above 9-year compulsory } \\
\text { education }\end{array}$ & 0.172 & 0.175 & 0.168 & NS \\
\hline Years of education & 5.847 & 6.072 & 5.470 & $* * *$ \\
\hline Migrant (above 1 month) & 0.243 & 0.283 & 0.176 & **** \\
\hline Migrant (above 3 months) & 0.218 & 0.253 & 0.159 & $* * *$ \\
\hline \multicolumn{5}{|c|}{ Family characteristics at baseline (2002) } \\
\hline Household size & 5.186 & 5.203 & 5.158 & NS \\
\hline Number of children under 15 & 1.870 & 1.864 & 1.881 & NS \\
\hline Number of adults & 3.199 & 3.289 & 3.048 & $* * *$ \\
\hline Number of elderly & 0.128 & 0.118 & 0.145 & $* * *$ \\
\hline Land per adult (mu) & 9.466 & 8.217 & 11.55 & $* *$ \\
\hline Dry land (\% of total land) & 0.934 & 0.911 & 0.971 & $* * *$ \\
\hline \multicolumn{5}{|l|}{ Village information } \\
\hline $\begin{array}{l}\text { Proportion of migrants in the } \\
\text { village labor force in } 2002(\%)\end{array}$ & 23.26 & 21.74 & 25.81 & $* * *$ \\
\hline $\begin{array}{l}\text { Lowest distance from village to } \\
\text { the county center }(\mathrm{km})\end{array}$ & 41.11 & 45.64 & 33.55 & $* * *$ \\
\hline Sample size & 2,673 & 1,673 & 1,000 & \\
\hline
\end{tabular}

Source: Survey data collected by Beijing Normal University and Hitotsubashi University in 2009. The village geography information (from village to county center) is from Ningxia Autonomous Regional Bureau of Surveying and Mapping, 1989. Ningxia Autonomous Region: Atlas of Counties. Beijing: China Map Publishing House. Additional information comes from the Statistical Bureau of Ningxia Hui Autonomous Region (2008). Land and Resources Ningxia Statistical Yearbook, China Statistics Press, or has been collected from Google distance calculator: www.daftlogic.com/projects-google-maps-distance-calculator.htm.

Notes: The mean test column indicates the significance level of mean differences between SLCP participating individuals and SLCP non-participating individuals. NS=not significant; *** significant at 1 percent. 
Table 4 - Migration shares by treatment and by year

\begin{tabular}{l|cc|c}
\hline Migration share & Participating group & Non-participating group & Difference between groups \\
\hline Year 2002 & $17.2 \%$ & $24 \%$ & $-6.8 \%$ \\
Year 2008 & $28.3 \%$ & $17.6 \%$ & $10.7 \%$ \\
\hline $\begin{array}{l}\text { Difference between } \\
\text { years }\end{array}$ & $11.1 \%$ & $-6.4 \%$ & DD $=\mathbf{1 7 . 5 \%}$ \\
\hline
\end{tabular}

Source: Survey data collected by Beijing Normal University and Hitotsubashi University in 2009. 
Table 5 - Individual migration transition from pre- to post-policy

\begin{tabular}{lccc}
\hline Individual situation change & & & \\
between 2002 and 2008 & Participating group & Non-participating group & Total \\
\hline Migrant to non-migrant & 42 & 114 & 156 \\
& $2.51 \%$ & $11.40 \%$ & $5.84 \%$ \\
No change & 1,403 & 836 & 2,239 \\
& $83.86 \%$ & $83.60 \%$ & $83.76 \%$ \\
Non-migrant to migrant & 228 & 50 & 278 \\
& $13.63 \%$ & $5.00 \%$ & $10.40 \%$ \\
Total & 1,673 & 1,000 & 2,673 \\
\hline
\end{tabular}

Source: Survey data collected by Beijing Normal University and Hitotsubashi University in 2009.

Note: "no change" means that the individual remained either migrant or non-migrant over the period. 
Table 6 - SLCP impact on migration decision

\begin{tabular}{|c|c|c|c|c|}
\hline & $\begin{array}{c}(1) \\
\text { Treatment }\end{array}$ & $\begin{array}{c}(2) \\
\text { Duration }\end{array}$ & $\begin{array}{c}(3) \\
\text { Area }\end{array}$ & $\begin{array}{c}(4) \\
\text { Intensity }\end{array}$ \\
\hline Year & $\begin{array}{c}-0.0641^{* * *} \\
(-4.78)\end{array}$ & $\begin{array}{c}-0.0468^{* * *} \\
(-3.62)\end{array}$ & $\begin{array}{l}0.0169 \\
(1.53)\end{array}$ & $\begin{array}{l}-0.0168 \\
(-1.41)\end{array}$ \\
\hline Treatment & $\begin{array}{c}-0.0474^{* * *} \\
(-3.11)\end{array}$ & & & \\
\hline Year x Treatment & $\begin{array}{l}0.175^{* * *} \\
(10.40)\end{array}$ & & & \\
\hline Duration & & $\begin{array}{c}-0.00943^{* * *} \\
(-2.89)\end{array}$ & & \\
\hline Year x Duration & & $\begin{array}{c}0.0344^{* * *} \\
(9.48)\end{array}$ & & \\
\hline Area & & & $\begin{array}{c}-0.000902^{* *} \\
(-2.37)\end{array}$ & \\
\hline Year x Area & & & $\begin{array}{c}0.00192^{* * *} \\
(4.60)\end{array}$ & \\
\hline Intensity & & & & $\begin{array}{c}-0.0825^{* * *} \\
(-3.46)\end{array}$ \\
\hline Year x Intensity & & & & $\begin{array}{c}0.207^{* * *} \\
(8.06)\end{array}$ \\
\hline Gender (male) & $\begin{array}{l}0.248^{* * *} \\
(21.72)\end{array}$ & $\begin{array}{l}0.248^{* * *} \\
(21.75)\end{array}$ & $\begin{array}{l}0.248^{* * *} \\
(21.63)\end{array}$ & $\begin{array}{l}0.248^{* * *} \\
(21.69)\end{array}$ \\
\hline Age (years) & $\begin{array}{c}0.0306^{* * *} \\
(10.15)\end{array}$ & $\begin{array}{c}0.0307^{* * *} \\
(10.17)\end{array}$ & $\begin{array}{c}0.0307^{* * *} \\
(10.13)\end{array}$ & $\begin{array}{c}0.0306^{* * *} \\
(10.13)\end{array}$ \\
\hline Age squared & $\begin{array}{c}-0.000530^{* * *} \\
(-12.41)\end{array}$ & $\begin{array}{c}-0.000531^{* * *} \\
(-12.42)\end{array}$ & $\begin{array}{c}-0.000530^{* * *} \\
(-12.36)\end{array}$ & $\begin{array}{c}-0.000530^{* * *} \\
(-12.38)\end{array}$ \\
\hline Married & $\begin{array}{c}-0.00445 \\
(-0.18)\end{array}$ & $\begin{array}{c}-0.00572 \\
(-0.23)\end{array}$ & $\begin{array}{c}-0.00674 \\
(-0.28)\end{array}$ & $\begin{array}{c}-0.00504 \\
(-0.21)\end{array}$ \\
\hline Hui nationality & $\begin{array}{l}0.0175 \\
(1.35)\end{array}$ & $\begin{array}{l}0.0170 \\
(1.32)\end{array}$ & $\begin{array}{l}0.0144 \\
(1.10)\end{array}$ & $\begin{array}{l}0.0143 \\
(1.10)\end{array}$ \\
\hline Primary education \& below & $\begin{array}{l}0.0337 \\
(1.51)\end{array}$ & $\begin{array}{l}0.0344 \\
(1.54)\end{array}$ & $\begin{array}{l}0.0325 \\
(1.44)\end{array}$ & $\begin{array}{l}0.0343 \\
(1.53)\end{array}$ \\
\hline Junior middle school & $\begin{array}{c}0.132^{* * * *} \\
(6.23)\end{array}$ & $\begin{array}{c}0.133^{* * *} \\
(6.26)\end{array}$ & $\begin{array}{c}0.133^{* * *} \\
(6.27)\end{array}$ & $\begin{array}{c}0.134^{* * * *} \\
(6.29)\end{array}$ \\
\hline Number of children under 15 & $\begin{array}{c}-0.0117^{* *} \\
(-2.08)\end{array}$ & $\begin{array}{c}-0.0118^{* *} \\
(-2.08)\end{array}$ & $\begin{array}{c}-0.0110^{*} \\
(-1.91)\end{array}$ & $\begin{array}{l}-0.0111^{*} \\
(-1.95)\end{array}$ \\
\hline Number of elderly & $\begin{array}{c}-0.0323^{* *} \\
(-2.13)\end{array}$ & $\begin{array}{c}-0.0324^{* *} \\
(-2.15)\end{array}$ & $\begin{array}{c}-0.0342^{* *} \\
(-2.23)\end{array}$ & $\begin{array}{c}-0.0327^{* *} \\
(-2.13)\end{array}$ \\
\hline Number of adults & $\begin{array}{c}0.0183^{* * *} \\
(2.91)\end{array}$ & $\begin{array}{c}0.0184^{* * *} \\
(2.91)\end{array}$ & $\begin{array}{c}0.0192^{* * *} \\
(3.02)\end{array}$ & $\begin{array}{c}0.0194^{* * *} \\
(3.05)\end{array}$ \\
\hline Land per adult & $\begin{array}{c}-0.000644^{*} \\
(-1.71)\end{array}$ & $\begin{array}{c}-0.000723^{*} \\
(-1.90)\end{array}$ & $\begin{array}{c}-0.000961^{* *} \\
(-2.50)\end{array}$ & $\begin{array}{c}-0.000841^{* *} \\
(-2.20)\end{array}$ \\
\hline$\%$ of migrants in the village labor force & $\begin{array}{c}0.00648^{* * *} \\
(9.58)\end{array}$ & $\begin{array}{c}0.00640^{* * *} \\
(9.45)\end{array}$ & $\begin{array}{c}0.00608^{* * * *} \\
(8.77)\end{array}$ & $\begin{array}{c}0.00616^{* * *} \\
(9.06)\end{array}$ \\
\hline Lowest distance to the county center & $\begin{array}{c}-0.000456^{*} \\
(-1.74)\end{array}$ & $\begin{array}{c}-0.000428 \\
(-1.63)\end{array}$ & $\begin{array}{c}-0.000294 \\
(-1.14)\end{array}$ & $\begin{array}{c}-0.000342 \\
(-1.30)\end{array}$ \\
\hline Constant & $\begin{array}{c}-0.457^{* * *} \\
(-9.13)\end{array}$ & $\begin{array}{c}-0.460^{* * *} \\
(-9.22)\end{array}$ & $\begin{array}{c}-0.470^{* * *} \\
(-9.36)\end{array}$ & $\begin{array}{c}-0.461^{* * *} \\
(-9.17)\end{array}$ \\
\hline $\begin{array}{l}N \\
R^{2}\end{array}$ & $\begin{array}{l}5,316 \\
0221\end{array}$ & $\begin{array}{l}5,316 \\
0219\end{array}$ & $\begin{array}{l}5,308 \\
0211\end{array}$ & 5,316 \\
\hline
\end{tabular}

Source: Survey data collected by Beijing Normal University and Hitotsubashi University in 2009.

Notes: The following explanatory variables are measured at baseline (2002): age, age squared, number of children under 15, number of elderly, number of adults, land per adult and percentage of migrants in the village labor force. Robust standard errors are adjusted for clustering by households. $t$ statistics in parentheses.*: Significant at $10 \%$. **: significant at $5 \% . * * *$ : significant at $1 \%$. 
Table 7 - SLCP impact on migration decision by sub-group

\begin{tabular}{|c|c|c|c|c|c|}
\hline & Gender & $\begin{array}{c}\text { Age } \\
\text { Age 15-29 }\end{array}$ & Age $30-39$ & Age $40-49$ & Age $50-65$ \\
\hline Year & $\begin{array}{l}-0.0184 \\
(-1.25)\end{array}$ & $\begin{array}{c}-0.0330^{* *} \\
(-2.45)\end{array}$ & $\begin{array}{c}-0.0532^{* * *} \\
(-3.48)\end{array}$ & $\begin{array}{c}-0.0569^{* * *} \\
(-3.85)\end{array}$ & $\begin{array}{c}-0.0664^{* * *} \\
(-4.50)\end{array}$ \\
\hline Treatment & $\begin{array}{c}-0.0290^{*} \\
(-1.82)\end{array}$ & $\begin{array}{c}-0.0283^{*} \\
(-1.88)\end{array}$ & $\begin{array}{c}-0.0337^{* *} \\
(-2.06)\end{array}$ & $\begin{array}{c}-0.0499^{* * *} \\
(-2.97)\end{array}$ & $\begin{array}{c}-0.0583^{* * *} \\
(-3.57)\end{array}$ \\
\hline Year $\mathrm{x}$ Treatment & $\begin{array}{l}0.105^{* * * *} \\
(5.77)\end{array}$ & $\begin{array}{c}0.135^{* * *} \\
(7.44)\end{array}$ & $\begin{array}{c}0.176^{* * *} \\
(9.13)\end{array}$ & $\begin{array}{c}0.178^{* * *} \\
(9.54)\end{array}$ & $\begin{array}{c}0.187^{* * * *} \\
(10.11)\end{array}$ \\
\hline Male & $\begin{array}{l}0.273^{* * *} \\
(12.76)\end{array}$ & $\begin{array}{l}0.240^{* * * *} \\
(21.16)\end{array}$ & $\begin{array}{l}0.239^{* * *} \\
(21.16)\end{array}$ & $\begin{array}{l}0.240^{* * * *} \\
(21.15)\end{array}$ & $\begin{array}{l}0.240^{* * *} \\
(21.17)\end{array}$ \\
\hline Year x Treatment x Male & $\begin{array}{c}0.135^{* * *} \\
(4.52)^{* * *}\end{array}$ & & & & \\
\hline Year x Male & $\begin{array}{c}-0.0892^{+3 x} \\
(-3.77)\end{array}$ & & & & \\
\hline Treatment x Male & $\begin{array}{c}-0.0356 \\
(-1.37)\end{array}$ & & & & \\
\hline Year x Treatment x Age 15-29 & & $\begin{array}{c}0.129^{* * *} \\
(3.30)\end{array}$ & & & \\
\hline Year x Age 15-29 & & $\begin{array}{c}-0.102^{* * *} \\
(-3.24)\end{array}$ & & & \\
\hline Treatment x Age 15-29 & & $\begin{array}{c}-0.0633^{*} \\
(-1.69)\end{array}$ & & & \\
\hline Year x Treatment x Age 30-39 & & & $\begin{array}{c}-0.00896 \\
(-0.22)\end{array}$ & & \\
\hline Year x Age 30-39 & & & $\begin{array}{c}-0.0472 \\
(-1.48)\end{array}$ & & \\
\hline Treatment x Age 30-39 & & & $\begin{array}{c}-0.0614^{*} \\
(-1.70)\end{array}$ & & \\
\hline Year x Treatment x Age 40-49 & & & & $\begin{array}{l}-0.0125 \\
(-0.33)\end{array}$ & \\
\hline Year x Age 40-49 & & & & $\begin{array}{l}-0.0464 \\
(-1.46)\end{array}$ & \\
\hline Treatment x Age 40-49 & & & & $\begin{array}{l}0.0115 \\
(0.31)\end{array}$ & \\
\hline Year x Treatment x Age 50-65 & & & & & $\begin{array}{c}-0.109^{* * *} \\
(-3.07)\end{array}$ \\
\hline Year x Age 50-65 & & & & & $\begin{array}{l}0.0209 \\
(0.75)_{* *}\end{array}$ \\
\hline Treatment x Age 50-65 & & & & & $\begin{array}{c}0.0942^{* *} \\
(2.58)\end{array}$ \\
\hline Age 15-29 & & $\begin{array}{c}0.360^{* * *} \\
(10.90)\end{array}$ & $\begin{array}{l}0.309^{* * *} \\
(14.10)\end{array}$ & $\begin{array}{l}0.310^{* * *} \\
(14.14)\end{array}$ & $\begin{array}{l}0.309^{* * *} \\
(14.11)\end{array}$ \\
\hline Age 30-39 & & $\begin{array}{c}0.201^{* * *} \\
(7.70)\end{array}$ & $\begin{array}{c}0.265^{* * *} \\
(7.36)\end{array}$ & $\begin{array}{c}0.201^{* * * *} \\
(7.69)\end{array}$ & $\begin{array}{c}0.201^{* * *} \\
(7.69)\end{array}$ \\
\hline Age $40-49$ & & $\begin{array}{c}0.0895^{* * *} \\
(3.50)\end{array}$ & $\begin{array}{c}0.0893^{* * *} \\
(3.49)\end{array}$ & $\begin{array}{l}0.109^{* * * *} \\
(2.90)\end{array}$ & $\begin{array}{c}0.0894^{* * *} \\
(3.49)\end{array}$ \\
\hline Age $50-65$ & & $\begin{array}{l}0.0138 \\
(0.49)\end{array}$ & $\begin{array}{c}0.0141 \\
(0.51)\end{array}$ & $\begin{array}{l}0.0139 \\
(0.50)\end{array}$ & $\begin{array}{l}-0.0217 \\
(-0.57)\end{array}$ \\
\hline Age (years) & $\begin{array}{c}0.0306^{* * *} \\
(10.16)\end{array}$ & & & & \\
\hline Age squared & $\begin{array}{c}-0.000530^{* * *} \\
(-12.42)\end{array}$ & & & & \\
\hline Hui nationality & $\begin{array}{l}0.0175 \\
(1.35)\end{array}$ & $\begin{array}{l}0.0154 \\
(1.24)\end{array}$ & $\begin{array}{c}0.0170 \\
(1.37)\end{array}$ & $\begin{array}{l}0.0155 \\
(1.25)\end{array}$ & $\begin{array}{l}0.0153 \\
(1.24)\end{array}$ \\
\hline Primary education $\&$ below & $\begin{array}{l}0.0340 \\
(1.52)\end{array}$ & $\begin{array}{c}0.00851 \\
(0.39)\end{array}$ & $\begin{array}{c}0.00757 \\
(0.34)\end{array}$ & $\begin{array}{c}0.00852 \\
(0.39)\end{array}$ & $\begin{array}{c}0.00798 \\
(0.36)\end{array}$ \\
\hline Junior middle school & $\begin{array}{c}0.132^{* * *} \\
(6.22)\end{array}$ & $\begin{array}{c}0.116^{* * * *} \\
(5.62)\end{array}$ & $\begin{array}{l}0.117^{* * *} \\
(5.63)\end{array}$ & $\begin{array}{c}0.116^{* * *} \\
(5.63)\end{array}$ & $\begin{array}{c}0.116^{* * *} \\
(5.61)\end{array}$ \\
\hline
\end{tabular}




\begin{tabular}{lccccc} 
Married & -0.00425 & -0.0279 & -0.0277 & -0.0279 & -0.0279 \\
& $(-0.17)$ & $(-1.26)$ & $(-1.25)$ & $(-1.26)$ & $(-1.26)$ \\
Number of children under 15 & $-0.0117^{* *}$ & 0.00403 & 0.00381 & 0.00406 & 0.00379 \\
& $(-2.09)$ & $(0.72)$ & $(0.68)$ & $(0.72)$ & $(0.67)^{* *}$ \\
Number of elderly & $-0.0323^{* *}$ & $-0.0347^{* *}$ & $-0.0353^{* *}$ & $-0.0348^{* *}$ & $-0.0351^{* *}$ \\
& $(-2.13)$ & $(-2.41)$ & $(-2.44)$ & $(-2.41)$ & $(-2.43)$ \\
Number of adults & $0.0184^{* * *}$ & -0.00345 & -0.00358 & -0.00343 & -0.00328 \\
& $(2.92)$ & $(-0.54)$ & $(-0.57)$ & $(-0.54)$ & $(-0.52)$ \\
Land per adult & $-0.000653^{*}$ & -0.000422 & -0.000444 & -0.000419 & -0.000431 \\
& $(-1.73)^{* * *}$ & $(-1.06)^{* * *}$ & $(-1.10)^{* *}$ & $(-1.05)^{* * *}$ & $(-1.08)^{* *}$ \\
\% of migrants in the village & $0.00649^{* *}$ & $0.00641^{* * *}$ & $0.00644^{* * *}$ & $0.00641^{* * *}$ & $0.00642^{* * *}$ \\
labor force & $(9.57)$ & $(9.75)$ & $(9.83)$ & $(9.75)$ & $(9.74)$ \\
Lowest distance to the county & $-0.000453^{*}$ & $-0.000432^{*}$ & $-0.000419^{*}$ & $-0.000432^{*}$ & $-0.000432^{*}$ \\
center & $(-1.73)$ & $(-1.73)$ & $(-1.68)$ & $(-1.73)$ & $(-1.73)$ \\
Constant & $-0.470^{* * *}$ & $-0.216^{* * *}$ & $-0.216^{* * *}$ & $-0.204^{* * *}$ & $-0.196^{* * *}$ \\
& $(-9.45)$ & $(-5.91)$ & $(-5.82)$ & $(-5.50)$ & $(-5.32)$ \\
\hline$N$ & 5,316 & 5,316 & 5,316 & 5,316 & 5,316 \\
$R^{2}$ & 0.223 & 0.246 & 0.247 & 0.246 & 0.246 \\
\hline
\end{tabular}

Source: Survey data collected by Beijing Normal University and Hitotsubashi University in 2009.

Notes: See Table 6. 
Table 8 - SLCP impact on migration decision by sub-group

\begin{tabular}{|c|c|c|c|c|}
\hline & $\begin{array}{c}\text { Education } \\
\text { Primary }\end{array}$ & Middle school & Married & Hui \\
\hline Year & $\begin{array}{c}-0.0292 \\
(-1.45)\end{array}$ & $\begin{array}{c}-0.0635^{* * *} \\
(-4.71)\end{array}$ & $\begin{array}{l}0.0228 \\
(0.93)\end{array}$ & $\begin{array}{c}-0.0575^{* * *} \\
(-3.33)\end{array}$ \\
\hline Treatment & $\begin{array}{c}-0.0471^{* *} \\
(-2.00)\end{array}$ & $\begin{array}{c}-0.0476^{* * *} \\
(-3.10)\end{array}$ & $\begin{array}{l}-0.0101 \\
(-0.40)\end{array}$ & $\begin{array}{c}-0.0735^{* * * *} \\
(-3.62)\end{array}$ \\
\hline Year $\mathrm{x}$ Treatment & $\begin{array}{l}0.156^{* * * *} \\
(6.15)\end{array}$ & $\begin{array}{l}0.174^{* * * *} \\
(10.21)\end{array}$ & $\begin{array}{l}0.153^{* * * *} \\
(4.93)\end{array}$ & $\begin{array}{l}0.148^{* * * *} \\
(7.18)\end{array}$ \\
\hline Year $\mathrm{x}$ Treatment $\mathrm{x}$ Primary ed. & $\begin{array}{l}0.0311 \\
(0.96)\end{array}$ & & & \\
\hline Year x Primary ed. & $\begin{array}{c}-0.0628^{* *} \\
(-2.46)\end{array}$ & & & \\
\hline Treatment x Primary ed. & $\begin{array}{c}0.00204 \\
(0.07)\end{array}$ & & & \\
\hline Year $x$ Treatment $x$ Middle ed. & & $\begin{array}{l}0.0298 \\
(0.37)\end{array}$ & & \\
\hline Year x Middle ed. & & $\begin{array}{l}-0.0162 \\
(-0.25)\end{array}$ & & \\
\hline Treatment x Middle ed. & & $\begin{array}{c}0.00411 \\
(0.10)\end{array}$ & & \\
\hline Year $\mathrm{x}$ Treatment $\mathrm{x}$ Married & & & $\begin{array}{l}0.0286 \\
(0.77)\end{array}$ & \\
\hline Year x Married & & & $\begin{array}{c}-0.125^{* * *} \\
(-4.26)\end{array}$ & \\
\hline Treatment x Married & & & $\begin{array}{l}-0.0529^{*} \\
(-1.68)\end{array}$ & \\
\hline Year $\mathrm{x}$ Treatment $\mathrm{x}$ Hui & & & & $\begin{array}{c}0.0691^{* *} \\
(1.97)\end{array}$ \\
\hline Year x Hui & & & & $\begin{array}{c}-0.0138 \\
(-0.51)\end{array}$ \\
\hline Treatment $x$ Hui & & & & $\begin{array}{c}0.0580^{*} \\
(1.95)\end{array}$ \\
\hline Male & $\begin{array}{l}0.248^{* * *} \\
(21.69)\end{array}$ & $\begin{array}{l}0.248^{* * *} \\
(21.76)\end{array}$ & $\begin{array}{l}0.248^{* * *} \\
(21.66)\end{array}$ & $\begin{array}{l}0.248^{* * *} \\
(21.72)\end{array}$ \\
\hline Age (years) & $\begin{array}{c}0.0307^{* * *} \\
(10.19)\end{array}$ & $\begin{array}{c}0.0306^{* * *} \\
(10.05)\end{array}$ & $\begin{array}{c}0.0305^{* * *} \\
(10.13)\end{array}$ & $\begin{array}{c}0.0308^{* * *} \\
(10.22)\end{array}$ \\
\hline Age squared & $\begin{array}{c}-0.000532^{* * *} \\
(-12.45)\end{array}$ & $\begin{array}{c}-0.000530^{* * *} \\
(-12.29)\end{array}$ & $\begin{array}{c}-0.000529^{* * *} \\
(-12.41)\end{array}$ & $\begin{array}{c}-0.000533^{* * *} \\
(-12.47)\end{array}$ \\
\hline Hui nationality & $\begin{array}{l}0.0178 \\
(1.38)\end{array}$ & $\begin{array}{l}0.0173 \\
(1.34)\end{array}$ & $\begin{array}{l}0.0173 \\
(1.34)\end{array}$ & $\begin{array}{l}-0.0308 \\
(-1.29)\end{array}$ \\
\hline Primary education $\&$ below & $\begin{array}{c}0.0542^{*} \\
(1.83)\end{array}$ & $\begin{array}{l}0.0352 \\
(1.54)\end{array}$ & $\begin{array}{l}0.0335 \\
(1.50)\end{array}$ & $\begin{array}{l}0.0366 \\
(1.64)\end{array}$ \\
\hline Junior middle school & $\begin{array}{c}0.133^{* * *} \\
(6.23)\end{array}$ & $\begin{array}{l}0.134^{* * * *} \\
(6.07)\end{array}$ & $\begin{array}{l}0.133^{* * * *} \\
(6.25)\end{array}$ & $\begin{array}{c}0.134^{* * *} \\
(6.31)\end{array}$ \\
\hline Married & $\begin{array}{c}-0.00466 \\
(-0.19)\end{array}$ & $\begin{array}{c}-0.00409 \\
(-0.17)\end{array}$ & $\begin{array}{l}0.0830^{* *} \\
(2.58)\end{array}$ & $\begin{array}{c}-0.00524 \\
(-0.22)\end{array}$ \\
\hline Number of children under 15 & $\begin{array}{c}-0.0116^{* *} \\
(-2.05)\end{array}$ & $\begin{array}{c}-0.0117^{* *} \\
(-2.06)\end{array}$ & $\begin{array}{c}-0.0116^{* *} \\
(-2.07)\end{array}$ & $\begin{array}{c}-0.0131^{* * *} \\
(-2.33)\end{array}$ \\
\hline Number of elderly & $\begin{array}{c}-0.0322^{* *} \\
(-2.13)\end{array}$ & $\begin{array}{c}-0.0323^{* *} \\
(-2.12)\end{array}$ & $\begin{array}{c}-0.0319^{* * *} \\
(-2.10)\end{array}$ & $\begin{array}{c}-0.0324^{* * *} \\
(-2.15)\end{array}$ \\
\hline Number of adults & $\begin{array}{c}0.0184^{* * *} \\
(2.93)\end{array}$ & $\begin{array}{c}0.0183^{* * *} \\
(2.93)\end{array}$ & $\begin{array}{c}0.0184^{* * *} \\
(2.92)\end{array}$ & $\begin{array}{c}0.0191^{* * *} \\
(3.07)\end{array}$ \\
\hline Land per adult & $\begin{array}{c}-0.000660^{*} \\
(-1.76)\end{array}$ & $\begin{array}{c}-0.000643^{*} \\
(-1.71)\end{array}$ & $\begin{array}{c}-0.000628^{*} \\
(-1.66)\end{array}$ & $\begin{array}{c}-0.000877^{* *} \\
(-2.27)\end{array}$ \\
\hline $\begin{array}{l}\% \text { of migrants in the village labor } \\
\text { force }\end{array}$ & $\begin{array}{l}0.00653^{* * *} \\
(9.68)\end{array}$ & $\begin{array}{l}0.00647^{* * *} \\
(9.59)\end{array}$ & $\begin{array}{l}0.00647^{* * *} \\
(9.58)\end{array}$ & $\begin{array}{l}0.00711^{* * *} \\
(10.60)\end{array}$ \\
\hline $\begin{array}{l}\text { Lowest distance to the county } \\
\text { center }\end{array}$ & $\begin{array}{c}-0.000447^{*} \\
(-1.70)\end{array}$ & $\begin{array}{c}-0.000455^{*} \\
(-1.74)\end{array}$ & $\begin{array}{c}-0.000461^{*} \\
(-1.76)\end{array}$ & $\begin{array}{c}-0.000366 \\
(-1.38)\end{array}$ \\
\hline
\end{tabular}




\begin{tabular}{lcccc} 
Constant & $-0.471^{* * *}$ & $-0.457^{* * *}$ & $-0.515^{* * *}$ & $-0.453^{* * *}$ \\
& $(-9.22)$ & $(-9.11)$ & $(-10.04)$ & $(-9.09)$ \\
\hline$N$ & 5,316 & 5,316 & 5,316 & 5,316 \\
$R^{2}$ & 0.222 & 0.221 & 0.226 & 0.225 \\
\hline
\end{tabular}

Source: Survey data collected by Beijing Normal University and Hitotsubashi University in 2009.

Notes: See Table 6. 
Table 9 - The effect of SLCP program on migration with PSM method

\begin{tabular}{lcccc}
\hline Method (parameters) & $\begin{array}{c}\text { Number of } \\
\text { treated }\end{array}$ & $\begin{array}{c}\text { Number of } \\
\text { controls }\end{array}$ & $\begin{array}{c}\text { ATT } \\
\text { coefficient }\end{array}$ & Std. Err. \\
\hline $\begin{array}{l}\text { Nearest-Neighbor matching } \\
\text { (10 neighbors; caliper value: 0.001) }\end{array}$ & 3,072 & 1,996 & $0.1619^{* * *}$ & 0.0137 \\
$\begin{array}{l}\text { Radius matching } \\
\text { (caliper value: 0.001) }\end{array}$ & 3,072 & 1,996 & $0.1602^{* * *}$ & 0.0136 \\
$\begin{array}{l}\text { Kernel matching } \\
\text { (Epanechnikov kernel; bandwith: 0.06) }\end{array}$ & 3,166 & 1,996 & $0.1576^{* * *}$ & 0.0115 \\
$\begin{array}{l}\text { Kernel matching } \\
\text { (Epanechnikov kernel; bandwith: 0.03) }\end{array}$ & 3,166 & 1,996 & $0.1607^{* * *}$ & 0.0116 \\
$\begin{array}{l}\text { Kernel matching } \\
\text { (Gaussian kernel; bandwith: 0.01) }\end{array}$ & 3,166 & 1,996 & $0.1620^{* * *}$ & 0.0115 \\
\hline
\end{tabular}

Source: Survey data collected by Beijing Normal University and Hitotsubashi University in 2009.

Notes: Standard errors for the matching estimates are bootstrapped standard errors using 100 replicates.

The propensity score is estimated using a logit of treatment status on individual characteristics (gender, initial age, marital status, years of education, local cadre status), initial household and village characteristics (household size, number of elderly, migration network), and a number of interaction terms. A common support is imposed for each matching method by dropping 5 percent of the treatment observations at which the score density of the control observations is the lowest. ${ }^{* * *}$ : significant at $1 \%$. 
Figure 1 - Map of the surveyed prefecture-level cities and counties in Ningxia Hui Autonomous Region

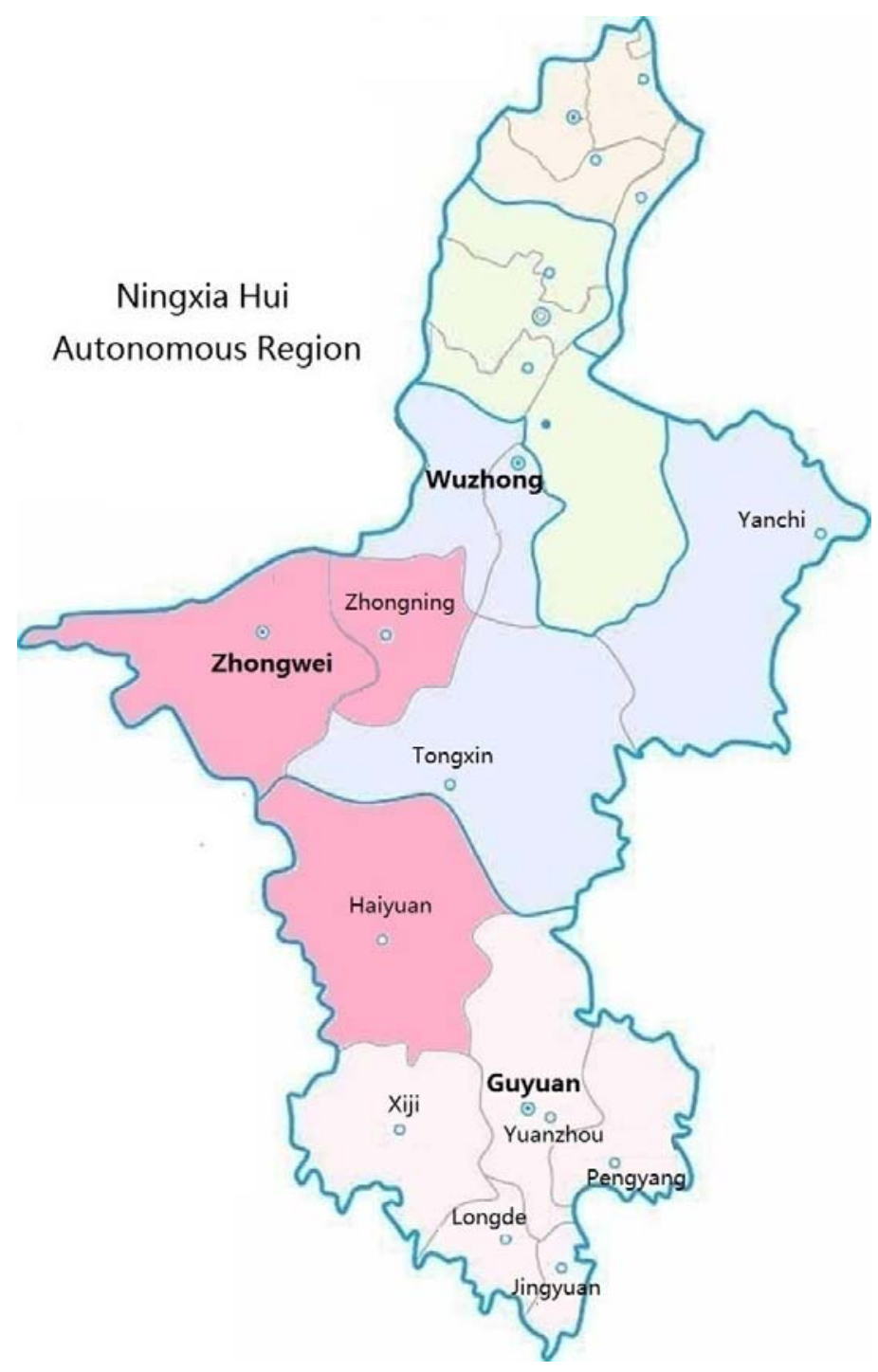


Figure 2 - Histogram of propensity scores by treatment status

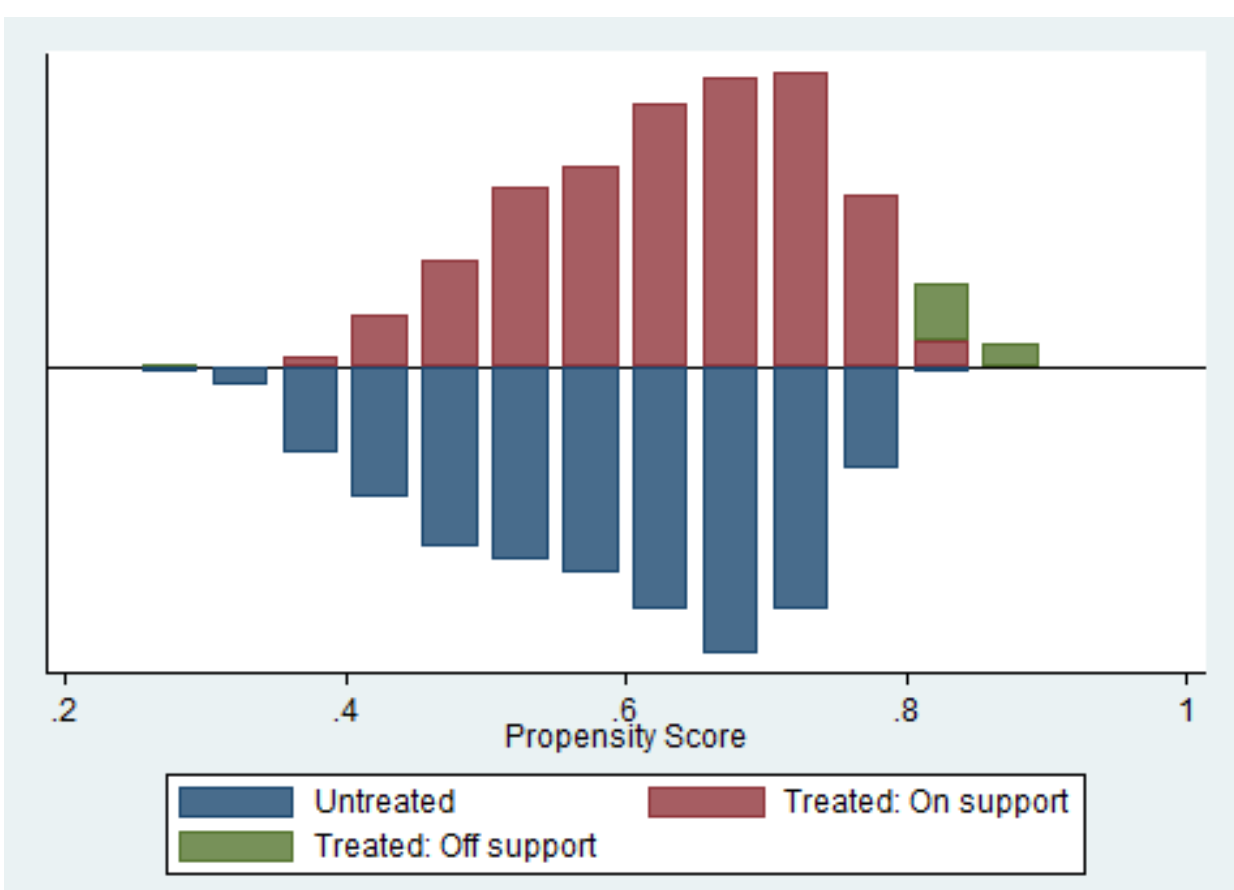

Source: Survey data collected by Beijing Normal University and Hitotsubashi University in 2009. Notes: Matching estimator: Kernel matching (Gaussian kernel; bandwith: 0.01). 